\title{
Promoting Freedom, Responsibility, and Learning in the Classroom: The Learning Covenant a Decade Later
}

\author{
Fred Glennon \\ LeMoyne College
}

\begin{abstract}
This essay discusses an approach to teaching religious studies in a general education or core curriculum that I have experimented with for the last decade, which I call the "Learning Covenant." The Learning Covenant brings together various pedagogical theories, including transformational, experiential, contract, and cooperative learning, in an attempt to address diverse learning styles, multiple intelligences, and student learning assessment. It has advantages over more traditional teacher-directed approaches to teaching, including meeting student resistance to "required" courses head-on by inviting them to identify learning needs regardless of chosen vocation and meeting them in the context of a religious studies course, recognizing the multiple ways in which students learn and providing a variety of opportunities for students to express their learning, and allowing students opportunity to take increased responsibility for their own learning. The essay will focus on the Learning Covenant's development, components, strengths, and drawbacks.
\end{abstract}

\section{Introduction}

In his book, The Courage to Teach, Parker Palmer makes two important assertions that reflect my educational philosophy and practice. First, he contends that we cannot reduce good teaching to technique. Instead, good teaching comes from the identity and integrity of the teacher (Palmer 1998, 10). What he means is that as we come to grips with our selfhood as teachers - the forces that shape us, the values we hold, the commitments we make - we can learn techniques that reveal our personhood as teachers. Second, Palmer argues that community is at the heart of reality and thus at the heart of education (Palmer 1998, 97). Education occurs within a teaching-learning community that acknowl- edges the interrelationship between teachers, students, and the truths we seek together.

Ten years ago, I introduced the concept of a Learning Covenant as a way of structuring the introductory course in religious studies (and subsequently all of my courses) to embody Palmer's ideas (Glennon 1995). That early covenant was established on certain foundations that reflected who I was as a teacher and what I understood about the nature of the teaching-learning environment. I was tired of the teacher-directed, passive learning approaches common in the classroom that treated students as empty vessels. I was interested in involving students more directly in their learning. Active, student-centered learning strategies promised a new direction (Barr and Tagg 1995). Moreover, I wanted to encourage such values as freedom, responsibility, and community among my students - values that are foundational to the tradition of covenant community that shapes my worldview (see Glennon 1999, 19-20). In its best communal sense, the covenant tradition recognizes the value of all persons and seeks to generate a community that enables and requires the participation and contributions of all members. It is very difficult to promote those values in a traditional classroom, which often embodies an authoritarian, hierarchical model of teaching. Instead, I sought to empower students, using techniques and strategies that promoted student freedom, self-respect, and collaboration, and provided ways for students to take more responsibility for their learning.

\section{The Individual Learning Covenant in Theory and Practice}

The first part of the Learning Covenant, the individual learning covenanting process, rested on adult learning theories of self-directed learning and their practical 
application to individual contract learning. Independent or Individual Learning Contracts (ILC) developed out of research related to adult learning. What researchers discovered is that adults learn more deeply and permanently when they have a strong role in the planning and carrying out of their learning efforts. Contract learning engages students in the learning process by building a program of study upon the compelling interests of each student. Instead of asking herself or himself, "How can I teach so that students will be motivated to learn?" the teacher asks students, "What do you want to learn?" This approach empowers the student by giving him or her a large measure of control over what learning takes place, thereby providing ownership of learning (Freie 1992).

Contract learning is an approach to adult learning that makes certain assumptions. First, learners need to know why it is they are learning what they are learning and how it will benefit them if they learn it or hinder them if they do not. Second, learners need to be selfdirected. This is based on the notion that the selfconception of an adult includes being responsible for oneself. If a learner perceives herself or himself as being responsible, then she or he needs to be perceived and treated by others as someone who is capable of assuming such responsibility. Third, learners have the need to have their experiences taken into account. There is diversity among adults in terms of life experiences, interests, styles of learning, and the like, that adults want taken into account in the development of their learning experiences. Fourth, learning should be geared to the learners' readiness to learn, which occurs when they experience needs and interests that learning will satisfy. Finally, the learning process should encourage intrinsic motivations to learn, which include self-esteem, responsibility, creativity, and self-fulfillment (Hiemstra and Sisco 1990, chapter 8).

Contract learning replaces the traditional contenttransmission structure with a process structure for learning. It does so by engaging students in the learning process to a far greater degree; and, the more engaged students are, the more they will learn. Contract learning also replaces teacher-imposed discipline in the learning process with student self-discipline. As a result, the student-teacher relationship becomes one of colleagues and mutual learners seeking to achieve mutually agreedupon objectives. Moreover, contract learning sharpens students' skills of self-directed learning, providing them with tools that will enable them to learn from any experience and in any environment they encounter in their lives (Knowles 1986, 46-47).

The individual learning covenants I use follow contract learning theory by including learning objectives (the knowledge, skills, attitudes, and values to be acquired by the learner); learning resources and strategies (the activities in which the learner will engage to accomplish the objectives); evidence of accomplishment (the completed activities that demonstrate completion of the objectives); criteria and means for validating the evidence (the evaluation criteria and named persons who evaluate); and the target date for completion (Knowles 1986, 38). Because of the importance of grades to my institution and students, the learning covenants also include the weight students give to each completed objective.

As I engaged in more pedagogical research, I realized that the individual learning covenants also embody aspects of what is called "transformational learning," exemplified in the works of Freire, Shor, and Mezirow where transformation is understood as enabling adult students to critically examine and rethink prior cognitive and behavioral frameworks to become broader, more inclusive, and more self-regulated. One of those frameworks includes the education process itself. Mezirow rejects the traditional concept of teacherdirected education, where students are passive recipients of the teacher's expertise. Instead, he favors a collaborative educational experience, in which learners assume more control and self-direction. "The generally accepted model of adult education involves a transfer of authority from the educator to the learners; the successful educator works herself out of her job as educator and becomes a collaborative learner" (Mezirow 2000, 14-15). But achieving this requires a different approach with students. In place of what Paulo Freire called the "banking" method of education, in which students are passive recipients of the teacher's knowledge and expertise, the teaching-learning community must become dialogical, in which "both are simultaneously teachers and students (Freire 1970, 59).

In the context of my fairly homogeneous student population of passive learners ( 80 percent of whom are traditional age college students), it is important to induce this sort of conceptual and behavioral change and move students beyond the narrow confines of a teacher-directed or other-directed framework for learning about the world around them. Yet such a transfer of authority requires a certain level of trust in the students and in their developed ability to think and reason. Freire writes that the efforts of this type of educator must, from the outset, "coincide with those of the students to engage in critical thinking and the quest for mutual humanization. His efforts must be imbued with a profound trust in men and their creative power. To achieve this, he must be a partner of the students in his relation with them" (Freire 1970, 62).

Other learning theories also support this movement from other-directed learning to student-directed and dialogical learning, either individually or in collaboration. For example, John Dewey contends that the best learning takes place when students are given something to do, not something to learn (Dewey 1966, 154). Ira Shor 
affirms Dewey's insight when he argues that students should "experience education as something they do rather than as something done to them" (Shor 1992, $85)$. This means that the learner should be actively involved in shaping the purpose and direction of the learning that takes place. Dewey contends, "Setting up conditions which stimulate certain visible and tangible ways of acting is the first step. Making the individual a sharer or partner in the associated activity so that he feels its success as his success, its failure as his failure, is the completing step" (Dewey 1966, 14). I teach required courses, where student resistance is strong, and I can affirm that getting students to take responsibility for their learning lowers this resistance because it makes the learning more meaningful. Learning information and skills is more significant when students are able to make meaningful connections to their own goals and interests. This happens best when each becomes a partner in that learning by having the freedom and responsibility to determine in part how it will take place.

Experiential learning theories have built upon Dewey's contention that the best way to learn is through quality experiences. Dewey argued that while all education provides experiences, some of these experiences can be mis-educative if they do not further the growth of the student's learning and experience (Dewey 1997, 25). We want experiences that live fruitfully in future experiences. The Learning Covenant provides opportunities for students to become more self-directed in shaping and assessing their own learning experiences, and to work collaboratively to further the learning of all. These are essential skills for students to learn as they move beyond our classrooms into the institutions of work and citizenship. And these learning experiences, developing from other-directed toward more collaborative and selfdirected learning, are accompanied throughout by observation and reflection.

While affirming such self-direction, I am also aware of the potential pitfalls of this approach in theory and in practice. Just because college students are considered adults does not mean that they are automatically capable of such self-direction. Merriam suggests that such a shift in perspective requires a certain level of cognitive development that not every student possesses (Merriam 2004). Robert Kegan, a cognitivedevelopmental theorist, suggests the challenge is even greater. He differentiates between informative learning (changes in what we know) and transformative learning (changes in how we know). The latter is the primary goal that the Learning Covenant seeks, shifting students from other-directed frameworks to more self-directed frameworks for learning. "Educators seeking selfdirection from their adult students are not merely asking them to take on new skills, modify their learning style, or increase their self-confidence. They are asking many of them to change the whole way they understand them- selves, their world, and the relationship between the two. They are asking many of them to put at risk the loyalties and devotions that have made up the very foundation of their lives" (Kegan 2000, 67).

Kegan's point is that this shift in perspective can be a very painful process, not necessarily exhilarating. Students can feel guilt and shame when they make this shift. While providing students more autonomy and self-direction in their learning and expecting more responsibility from them are important goals, it is equally important to understand the students in the room so that we structure an environment to help them develop the skills they need to make this transition, rather than throwing the responsibility all on them. We should not focus so extensively on the goal that we ignore where our students are. Kegan rightly suggests that "all of us, as adult educators, need help in discerning how rapidly or gradually this shift in authority should optimally take place for that student, which is a function of how far he or she is along this particular bridge" (Kegan 2000, 66).

I have addressed this potential pitfall in part by requiring certain projects, rather than leaving all of the decisions entirely up to the students. For example, in my introductory course in religious studies, I require three graded activities that meet the general education objectives of the course (group/class participation, a critical/ reflective ritual observance, and a group final). These activities can count as much as 75 percent or as little as 40 percent of a student's grade. The same is true with regard to the cooperative classroom (about which I will say more in the next section). I do not abandon students to their own devices. Instead I provide a variety of ways to help them learn how to read a text critically, and I work with them to develop the interpersonal skills necessary for collaborative learning.

Even though many students do not initially have the skills for self-direction in their learning, it is important to help them recognize that self-directed learning is an important part of the developmental challenge they face as they move into the world of adulthood. As Gibbons writes, "Self-directed learning - by combining freedom with responsibility, reflection with action, and challenge with opportunity - is very compatible with these demands of development" (Gibbons 2004, 464).

In light of the differences in the students' developmental ability noted above, the first thing I try to do is discern the students' self-beliefs about learning - what Zimmerman refers to as the forethought phase of selfdirected learning (Zimmerman 2002, 68). Most of my students, especially the younger ones, are emerging from teacher-directed backgrounds where all of the tasks were set for them and they were never asked to set their own goals or to learn content and skills intrinsically satisfying to them. Thus, they come as passive learners, especially in required courses. To make the transition from 
dependent to self-directed learners, students need selfknowledge about their strengths and weaknesses as learners and their personal preferences for learning situations and environments (Knowles, Holton, and Swanson 1998, 167-168). That is why I have students write a reflective essay at the beginning of the semester in which they tell me about themselves as learners. Because students are seldom asked to do this, I provide a series of questions to prompt their thinking, such as: What kind of environment best enables you to learn? Do you learn best by visual aids? Or are you an auditory learner, learning through listening? What motivates you to learn? Are you self-motivated or do you need certain kinds of prompts and incentives? What kind of classroom environments have helped you learn the most over the years? What kinds of classroom environments have hindered your learning? In addition, this essay (which counts as part of their participation grade) provides learning disabled students the opportunity to identify their disabilities confidentially so that I can accommodate their needs. I use the information I gather from these essays to generate a profile of each student in the class, which I then use to structure classroom activities and assignments. These essays have helped me assess how ready individual students are to engage in the covenanting process. Moreover, the essays enable most students to get a sense of their own capabilities.

Recognizing that most come from teacher-directed environments, I provide students with a list of learning objectives that I (and the institution) hope to achieve in the course. These include some knowledge/ understanding objectives, some skills objectives, some values objectives, and some attitudinal objectives. My initial hope is that these objectives will provide guidance and direction to the learning experience. But as well, these objectives provide the framework to measure how well students are meeting the learning outcomes of the course. I build assessment mechanisms around these objectives, including student self-assessment instruments that measure how well they are meeting the course objectives.

However, meeting the course objectives only fulfills part of the covenant. To complete the covenant, students must also devise their own objectives that reflect their own personal needs and interests yet stay within the broad parameters of the course. Students can draw these from a list I provide, but I encourage them to develop their own objectives based on their interests and learning needs. (This process does take some initial time and patience, because most have little background in writing learning objectives.) Here again, the objectives students develop provide a framework for them to assess their own learning in the course. One significant aspect of these self-assessment instruments is that students are more conscious of their learning as it takes place and are more able to articulate what learning has occurred, the circumstances that contributed to that learning, and the elements that have hindered it.

Students fulfill their learning objectives through learning strategies and resources. As a starting point, I provide students with a list of learning activities that provide ideas about ways to meet their objectives (see http://webserver.lemoyne.edu/ glennon/200-act.htm for examples from an introductory course in religion). I require completion of at least some of these activities. The vast majority, however, are optional. For example, students could enhance their critical thinking skills through a series of focused thought papers or a critical review of a play or film. Students may acquire knowledge about a particular religious group or concept by taking a field trip, observing a ritual, or reviewing appropriate literature. Students are required to select activities that they deem appropriate for meeting their objectives. The list I provide is meant to be suggestive, not exhaustive. I encourage students to develop their own activities or strategies as well, and many do.

Each learning activity has some outcome or product attached to it that will provide evidence that the student has indeed met the objective in question. For example, evidence that the student took a field trip can consist of some written, oral, or video report to the class or to the professor. In addition, each learning activity has some evaluative criteria attached to it to verify that the student has met his or her objectives and to determine the quality of the work. I attach "evaluation criteria" to each activity on the list of suggested learning activities. I make every effort to insure that the criteria are appropriate to the learning objectives involved. My reason for including these criteria is my belief that students have a right to know the basis for evaluation prior to completion of the work - not only for me, but also for them. Zimmerman notes that the best learners evaluate their learning against some evaluative criteria rather than against other learners (which is so often the case for younger learners and can lead them to doubt in their abilities) (Zimmerman 2002, 69). This is why it is imperative to work with younger students to develop clear, concise, evaluative criteria against which to measure their learning so that they can experience some success and build confidence as learners. Students may change the evaluative criteria attached to an activity to make sure that these are consistent with what they intend to learn. Only those evaluation criteria listed with the learning activity on the covenant may be used by the professor to determine the quality of the work. In this way, there is mutual understanding between the student and the professor. This does not always eliminate disagreement between us, but it does tend to minimize it.

Zimmermann also contends that successful performance in self-regulated learning requires students to exercise some self-control and to self-observe how they are doing (Zimmerman 2002, 68). One way I encourage 
self-control is to ask students to set their own due dates. On the one hand, students are in the best position to determine when they have time to complete their activities and this enables them to control their own schedules. On the other hand, setting their own due dates pushes students to keep track of what they are doing and forces them to manage their time. If they come up against a due date they cannot meet, they observe the elements of what this means. What elements of their learning habits and learning styles limit their ability to meet self-imposed deadlines? What can they learn from this for future learning events? The only stipulation I make, early on in the course, is that students finish some activity during the first half of the semester so that they have some feedback on their learning. I have discovered that this requirement really depends upon the maturity level of students. As a result, I tend to enforce this stipulation more with freshmen and sophomores than with juniors and seniors (although there are exceptions in both cases). Further, I make students aware that, because of time and institutional constraints, the later they complete their activities, the less feedback they are likely to get from me.

Finally, students must determine the weight each activity will have in factoring their overall grade for the course. Students can split the weight each activity carries in their grade as they deem appropriate. They can even include activities that meet their learning objectives but carry no weight. My purpose in this is to create a classroom environment that places more emphasis on learning than on grades. Students at Le Moyne College are risk-adverse. They are afraid of failure; they are reluctant to enhance their learning or strengthen their weaker skills out of fear that their GPAs will fall. In many ways, our society has contributed to this fear of failure institutionally (by attaching continued financial support to the maintenance of a certain grade point average) and professionally (as more prospective employers use GPA as a screening device). By allowing students the option of placing no weight on a learning activity, I encourage them to develop their knowledge or skills without the fear of being "punished" by a poor grade. Moreover, because I want to evaluate their best work, I allow students to change the weight after the activity is completed and the grade is assessed. Students who do well on an activity can raise the weight, and students who do poorly can lower it.

Students are free to modify their covenants (objectives, activities, evaluation criteria, due dates, weights) throughout the semester. (Required activities must be completed, but there is room to adjust the weight attached to them.) This provision recognizes that learning is a process and takes place in the context of competing demands and constraints. The opportunity to modify covenants invites students to experiment with different approaches and strategies without getting locked in. When I first started using learning covenants, I placed a time limit on the modification of the covenant to encourage students to make better use of their time by getting feedback on their learning (and to enable me to manage my time). I stipulated that they could not make any changes during the last month of the semester. Now I vary this time limit depending upon the class. Generally, I allow students to submit a final allocation of weights on the last day of class.

The individual covenanting process continues to some degree throughout the semester. However, the parameters are generally set within the first two or three weeks. Depending upon their level of maturity, students discuss the content of the covenants either by meeting with me individually or by consulting with their peers. After this process, students turn in an initial covenant. If the covenant includes all of the elements noted above, I approve it. Otherwise I meet with the student individually to negotiate revisions.

Finally, in traditional classes, students seldom have the opportunity to take stock of the learning that has occurred during the course of a semester. The final phase of any self-directed learning process should be selfreflection, in which students evaluate their performance and their learning (Zimmerman 2002). Therefore I require short, two to four page, student self-assessment of learning essays at the end of the semester. The essays are not graded, but do factor in as a component of the participation grade. Aside from asking students to reflect upon how well they have met their learning objectives, the essays also ask them to note those things within and without the class that helped or hindered their learning. As well as helping students understand their learning process, these essays provide me with an additional source of information on ways to improve the courses I teach.

\section{Classroom Covenant and Structure}

The values of freedom and responsibility are advanced by the individual learning covenanting process. But another goal of my classes is to generate a sense of community in the classroom that is participatory and where all people have voice and say in the process. Students cannot learn about community and participation by reading alone; they must also practice them. To further these ends, I supplement individual learning covenants with a class covenant that involves students in decision-making about curriculum, evaluation, and future classroom deliberations, and which emphasizes that students (and the professor) have responsibilities to one another.

The class covenant process generally involves two class meetings (although additional meetings can be added). I provide groups of students with four basic elements of the syllabus: course content and objectives, 
student rights and responsibilities, evaluation, and ground rules for discussion. Attached to each area is a set of questions to spark student thinking and deliberation. The students are asked to look at the elements and make comments about them, including what they like and what they would like to change. One semester, for example, one of my Comparative Religious Ethics classes felt they had more than enough experience with Christian ethics and wanted to focus instead on the ethical traditions of other faiths. This required some reworking of the syllabus, but it provided more opportunity to focus in depth on the traditions we covered. In the area of evaluation, students will sometimes make different decisions about who will evaluate their work and the weight each evaluation will carry. Some classes welcome the opportunity for students to evaluate each other's work along with the professor; other classes prefer that the evaluations come solely from me. The ground rules for discussion list the principles that will guide our interactions in the classroom. These usually include rules such as showing respect by listening and not interrupting each other, making sure everyone has an opportunity to participate, and prohibiting putdowns of any sort.

Some people question this process, arguing that it takes away from course content. However, I agree with Parker Palmer, who contends that good learning in higher education "is always more process than product" (Palmer 1998, 94). This is especially true of my ethics classes. In my view, the process of creating the classroom and learning covenants is the essence of ethics: a group of people coming together to deliberate about what is appropriate and inappropriate, laying out the foundations for their relationships with one another, and holding one another accountable for keeping their promises. Students not only learn what ethics is, but practice being ethical in the process.

Community and participation are furthered by structuring the classroom on cooperative and collaborative learning models. Cooperative learning advocates contend that because humans are social and interdependent beings, we learn best in cooperation with one another (Slavin 1983). Traditional approaches to learning are based on competitive or individualized models. But these models do not tap the potential of students to contribute to the learning process. This is especially true at the college level, where students bring diverse experience, backgrounds, and skill levels to the classroom. Students are almost never encouraged, much less rewarded, for helping each other learn. However, when teachers encourage students to work together and provide incentives for them to learn from one another, in the vast majority of cases students will learn better. Many research studies support this claim (Johnson and Johnson 1990, 2002; Summers et al. 2005; Slavin 1991, 1995; Zimbardo et al. 2003).
Of course, placing students in group contexts does not necessarily mean they will function effectively as a group. Since our educational system is so dominated by competitive and individualized models of instruction, many students do not know how to work cooperatively. That is why cooperative learning advocates argue that social skills, such as leadership, decision-making, trustbuilding, communication, and conflict resolution must be taught as purposefully as academic skills (Johnson, Johnson, and Smith 1991). Moreover, teachers must insure that every student gets the opportunity to practice each of these group roles.

Engaging students to take responsibility for their learning through cooperative strategies has implications for the role of the teacher in the classroom. To move students from passive to active learning, the teacher must become a facilitator and resource person instead of an authority figure. This does not mean that the work of the teacher decreases. The opposite is the case. The teacher must make numerous planning decisions to insure the effective functioning of the group process, including the size and make-up of the group, and the set-up of the classroom. Moreover, the teacher should move from group to group while the students are working to monitor both the content of what is taught and the process by which it is taught, intervening where necessary, but in ways that invite the participation of the students.

Many faculty members see the value of class participation these days and reward it in the grading process. But often this means simply that students who come to class and say something during the course of the semester receive a few additional points (and those who do not have points deducted). Many students are frustrated by this. The criteria for their participation grades are often nebulous. Moreover, many students do not have the social skills to participate meaningfully in large group settings and thus can become marginalized from the classroom learning process. To encourage mutuality, participation, and cooperation in the classroom, the students and I work collaboratively during every class. A significant portion of a student's grade is based upon the collective results of group work as well as individual participation in those groups. I experiment with a variety of formal and informal cooperative learning activities, developing base groups and promoting positive interdependence through the use of jigsaw (discussed below), group finals, and teaching-learning assessment groups. All of these create space and opportunity for all students to participate meaningfully in the learning process and provide each a sense of their own ability to contribute to the learning that takes place.

Base groups, or what I call home groups, are semester-long, random, cooperative learning groups of four or five students with stable membership. Their primary responsibility is to provide each student the 
support, encouragement, and assistance he or she needs to learn. Home groups personalize the work and the course learning experiences (Johnson, Johnson, and Smith 1991). They help with the content of the course because classroom learning and assessment activities are generally done in these groups. They are also the primary avenues for class participation.

For many years I attempted to be systematic in my approach to assigning home groups instead of randomly selecting them. I gathered information on each student and used exercises during the first two weeks to see how students interacted to measure their group skills levels. I used this information to generate the most heterogeneous groups I could. However, I have since discovered that this process has seldom achieved better results than simply randomly assigning groups during the first day of class. All students need to learn and practice the skills necessary for groups to succeed. Moreover, within two weeks, most students become comfortable with their group members and resist any permanent regrouping. Instead, I maintain the initial home groups, work to develop the group skills within each group, and find additional avenues for students to interact with other members of the class.

Positive interdependence involves creating a situation (and an awareness) in which students (and the professor) are linked with one another in ways such that they can only meet their mutually shared goal by sharing resources and fulfilling their responsibilities to one another. In other words, we sink or swim together. I use a variety of methods to generate this positive interdependence in the classroom, but the most common are jigsaw, expert groups, and group finals.

Jigsaw is a cooperative strategy designed to promote positive interdependence among students (Aronson 1978). When I assign essays for review, I assign enough so that each member of a group will be responsible for a different one. During class, students from each of the different groups who have read the same essay meet together to discuss the essay and form expert groups. One of the problems with this approach in the past has been that students want to review every aspect of the essay. But the ten to fifteen minute time frame allotted for expert group discussion does not allow for this approach. Instead, I ask each student to complete a concise (one-page), written summary of each essay they read. They must summarize the central focus of the essay in two or three sentences, identify three points or ideas from the essay that support their assertion, and then they must raise one question or idea they want the class to discuss. Sometimes these summaries are posted electronically ahead of class, but they are always brought to class as the basis for discussion. In the expert groups, the students review each other's summaries to insure that each person understands the key elements of the essay and can present it to others. Then the expert group either leads class discussion on that essay or they return to their home groups to teach the contents of the essay to the members of their home group. Students in home groups must listen attentively to one another because each student is held accountable for the ideas in each essay (through exam, presentation, or some other format). A different way of doing jigsaw is to have students read the same material (such as a chapter in a book), but assign students different parts of the chapter to concentrate on. They then become the experts on that part of the chapter. My own experience, as well as empirical studies, suggests that sharing complementary information is beneficial to learners (see Buchs, Butera, and Mugny 2004).

A group final exam is an essay exam that students write cooperatively. The purpose of the exam is to have a thorough, intellectually stimulating, and useful discussion of course materials. The task is to demonstrate mastery and deeper-level understanding of the ideas and concepts presented in the course. To structure the process, I provide a number of integrative essays that relate material from many parts of the course. Often, these are written by the students themselves. The groups divide the essays and each member is responsible for becoming an expert on the related course materials. That person prepares a typed draft of the essay and leads a group discussion of the final exam question. In addition, each group member comes prepared to discuss the other questions and to learn from one another. The group generates one set of answers for the group and all members must agree with and be able to explain the answers. In addition to the completed essays, students evaluate the participation of each member of the group (including themselves) in the final process, according to participation criteria already established.

Finally, in recognition that the Learning Covenant includes the professor as well as the students, it is imperative for me to assess my contributions to the teaching-learning environment. I want to know that my course objectives - the knowledge, skills, and values objectives - are actually being reached. An important communal and participatory way to do this is through teaching-learning assessment groups. These groups include any student who wants to participate, but primarily those students who have chosen teaching assistant or process analyst as a learning activity. We meet biweekly to discuss what occurred in the previous weeks' classes and what will happen in the weeks ahead. I provide students with copies of my objectives and selected activities for each class ahead of time so that they can write comments as the class proceeds. In particular, I ask students to note if the learning objective for the class was achieved and what helped or hindered its achievement. At our meetings, we discuss their comments and make suggestions for how the class might be improved and what I need to do in future classes to 
ensure that the material is learned better. I keep their comments and notes on our discussions in a file to use as I prepare to teach the given material at a future time.

\section{Strengths and Drawbacks}

This approach to the teaching-learning environment has strengths both for students and for faculty. First, for the students, research supports the efficacy of self-regulated learning processes for student learning (see Zimmerman et al. 1996). The Learning Covenant encourages the involvement of the student at every level. Students are active in the formulation of what they will learn and how they will learn it, thereby increasing their interest and responsibility. In required courses, the context in which I usually teach, students are there to check off the box on their graduation form. The Learning Covenant recognizes this and pushes students to think and act beyond the course requirements toward some knowledge, skill, or attitude that can enhance their overall learning experience regardless of their chosen profession. Moreover, students are clear about what they are learning. By encouraging students to identify their learning needs and to write measurable objectives based on those needs, students have a direction for the learning for which they are responsible. This is immensely helpful for their own assessment of their learning. Students understand whether or not they have met their objectives and are encouraged to think about the reasons for that. Moreover, having clear evaluation criteria attached to each activity enables students to know more precisely what is required for this kind of activity.

Assuming the kind of freedom and responsibility for their learning that is central to this Learning Covenant prepares students well for graduate school and the work world. "Agency in their thoughts and actions is inseparable from agency in their lives, relating what they are learning to themselves and to their futures" (Gibbons 2004, 464). Graduate studies require students to set goals for themselves, to work at their own pace, and to identify what they want to learn. In the workplace, employers expect college graduates to be self-directing and to accomplish the tasks they set before themselves. Workers will not always be told what to do. Our graduates seek to become professionals of one sort or another. One of the hallmarks of professional life is autonomy and self-direction. The Learning Covenant sets our students on the road toward those goals.

A final strength of this approach for the student is that it attends to diverse student learning styles. Much has been made of late regarding the multiple intelligences and learning styles that students bring to the classroom. The flexibility and variability of the Learning Covenant respects this diversity and allows students to learn in ways that are appropriate to them, rather than to the professor. And finally, the Learning Covenant allows students to set their own pace within the semester, thus easily accommodating students with learning disabilities who often need more time on assignments and projects.

As for the professor, the Learning Covenant fits well with new paradigms of higher education that advocate learning-based over instruction-based approaches. The learning-based paradigm promotes active rather than passive forms of student learning, and the creation of an environment filled with instructional activities that involve students "doing things and thinking about the things they are doing" (Bonwell and Eison 1991, 2). Higher education is a process in which participants learn and practice the intrinsic virtues and values of freedom, responsibility, and community. The Learning Covenant makes these values central to the teaching-learning enterprise and engages students actively in the process from start to finish.

Moreover, the diversity of projects and activities involved in the Learning Covenant can make student evaluation more interesting. A frequent complaint on the part of faculty members is that grading the same papers or the same answers on tests can be the most tedious aspect of their work. But professors can learn to look at course material in a new way when they see how a concept or idea is manifest in a student's artwork, for example, rather than rehearsed in yet another paper. In the words of Freire, "The teacher is no longer merely the-one-who-teaches, but one who is himself taught in dialogue with the students, who in turn while being taught also teach. They become jointly responsible for a process in which they all grow" (Freire 1970, 67). There is still some tedium involved, but the diversity of projects and ideas represented make the toil less onerous.

This approach also has assessment mechanisms built into the process. As any student learning assessment advocate knows, you begin with measurable objectives and move toward mechanisms to assess how well those objectives are met. In the Learning Covenant, students are part of the assessment process throughout. They identify their learning needs and objectives, and reflect critically on them. This does not mean that a professor does not have to incorporate assessment mechanisms, but that they are at the forefront of the educational experience.

Finally, the primary reason for a professor to adopt this or a similar approach is that it pushes one to become "a reflective practitioner" (Schön 1983) and "a critically reflective teacher" (Brookfield 1995). This approach brings one's pedagogical assumptions and value commitments into full consciousness, providing insight into one's teaching practices and their relationship to student learning. In my experience, this reflective practice has also encouraged me to pursue what the Carnegie Foundation calls, "the scholarship of teaching and learning." 
I gather data and reflect critically upon my teaching practice and make it public for peer review, even review by my students, in order to enhance the teachinglearning process. The fact that you are reading this in a peer-reviewed journal adds to this dimension. (See also Glennon 2004.)

I would not be a responsible practitioner if I did not warn of the drawbacks of this pedagogical approach. Some of these have been mentioned above. Not every student is ready for the freedom and responsibility of the Learning Covenant. Most students come to us from teacher-directed contexts as passive learners. To assume that students can adapt easily to this new teachinglearning environment is not wise. With proper encouragement and guidance, however, most students make the transition well and enjoy the opportunities of the Learning Covenant. (Ninety-five percent of my student evaluations remark that they would not change the Learning Covenant even though they had difficulty adjusting at first.) Yet some students will not make the transition. The reasons may range from their own developmental limits to their resistance to change. Many students claim that there is not enough structure in this approach. What they mean is that they want the assignments and due dates set for them and they want to take notes on what the teacher thinks is important. They prefer a teacher-directed approach to learning. They often do not value the contributions of their peers to their learning. The structure is there, but they do not want to be the ones to construct it. For others, procrastination is a serious issue. They may get into trouble by waiting until the end to complete assignments.

Most of these problems can be avoided for most students if the professor takes the time to discern the capabilities of students through the self-assessment exercises noted above. Educating students about the benefits of more self-direction for their future and their development into adult responsibilities is also helpful. For those students who are either unable or unwilling to move in this direction, it is important to provide an out. For me, this means that I help them to find an alternative class that meets their requirements and provides for a teaching-learning environment that they feel more comfortable in.

For the professor, there are drawbacks as well. The Learning Covenant is labor-intensive both within and without the classroom. Working with students to construct their covenants, teaching them how to write clear objectives, and directing them to design appropriate activities can be time consuming. I have never taught a class with more than thirty-six students and so have no idea whether or not this approach is possible in much larger classes. (I have taught as many as 120 students in a semester and have used this approach with all of them.) Moreover, record keeping can be a problem. Because students individualize their activities and the weights attached to them, I have constructed a spreadsheet formula for each individual student. By allowing changes to their formulas, I have to readjust that spreadsheet on a periodic basis. Also, students can and do procrastinate and this may leave the professor with a tremendous amount of evaluation and grading at the end of the semester. Freedom in choice of due dates also means that I am grading all semester long. Inside the classroom, I spend a good bit of time and energy helping the process along, constructing cooperative activities for students to engage in, and teaching them appropriate group roles. Yet once the students take ownership, the workload becomes less. Finally, an approach that promotes freedom and responsibility on the part of students can lead to some tradeoffs between content and process. I find this less problematic in our discipline than it might be in others. But, ultimately, I think the tradeoffs are worth it because the students have the tools to learn the content on their own.

The drawbacks are not insurmountable, but overcoming them requires that one recognize one's limits personal, contextual, and institutional. Some professors may not want to grade all the time and would prefer set times for students to complete graded activities. Class size, level of student readiness, and so on, may affect one's ability to implement all or part of the Learning Covenant. Moreover, one's institutional context may not appreciate or reward this approach. A publish or perish setting may not allow the time to invest in such a labor-intensive teaching process. If any of these constraints exist, the Learning Covenant is very amenable to modification, as colleagues who have used one aspect or another of this approach have reported to me.

\section{Conclusion}

Using a Learning Covenant requires certain basic assumptions about learners and learning. Human beings have a natural potential for learning, and learning happens best when learners move from being passive recipients to active participants in the learning process. The shift to a Learning Covenant challenges learners to become more self-directed and encourages the freedom, responsibility, and cooperation such selfdirection requires. By helping students to develop learning objectives, select appropriate learning activities, set their weights and due dates, and assess the learning that takes place - all in a supportive community of fellow learners - the Learning Covenant has the potential to promote a teaching-learning environment of active participants.

Over the years of experimenting with the Learning Covenant, I have found that my experience mirrors that of the adult educator Malcolm Knowles. He evolved from seeing himself as a teacher to seeing himself as a facilitator of learning. In this move, he discovered that 
instead of being a content planner and transmitter, he was more of a process designer and manager, "which required relationship building, needs assessment, involvement of students in planning, linking students to learning resources, and encouraging student initiative" (Knowles, Holton, and Swanson 1998, 210). He claims that he has never been tempted since then to revert back to the role of the teacher. I feel the same way. The Learning Covenant will continue to evolve in light of new pedagogical insights, student needs and interests, and classroom dynamics. In view of the ways the Learning Covenant has enabled my students to experience freedom and growth as learners, has proven beneficial to my colleagues who have enthusiastically and successfully experimented with various aspects of this approach, and has brought together my own sense of identity and integrity as an educator who encourages freedom, responsibility, and community in the teachinglearning environment, I cannot imagine reverting back to a teacher-directed classroom.

\section{References}

Aronson, Elliot. 1978. The Jigsaw Classroom. Beverly Hills, Calif.: Sage Publications.

Barr, Robert. B., and John Tagg. 1995. "From Teaching to Learning: A New Paradigm for Undergraduate Education." Change (November/December): 13-25.

Bonwell, Charles C., and James A. Eison. 1991. Active Learning: Creating Excitement in the Classroom. ASHE-ERIC Higher Education Report 1991, no. 1. Washington, D.C.: George Washington University.

Brookfield, Stephen. 1995. Becoming a Critically Reflective Teacher. San Francisco, Calif.: Jossey-Bass Publishers.

Buchs, Céline, Fabrizio Butera, and Gabrielle Mugny. 2004. "Resource Interdependence, Student Interactions and Performance in Cooperative Learning." Educational Psychology 24, no. 3:291-314.

Dewey, John. 1966. Democracy and Education. New York: The Free Press.

Dewey, John. 1997. Experience and Education. New York: Simon \& Schuster.

Freie, John. 1992. "The Individual Learning Contract." PS: Political Science and Politics 25, no. 2:230-234.

Freire, Paulo. 1970. Pedagogy of the Oppressed. New York: Continuum Publishing.

Gibbons, Maurice. 2004. "Pardon Me, Didn't I Just Hear a Paradigm Shift?” Phi Beta Kappan 85, no. 6:461-467.

Glennon, Fred. 1995. "The Learning Covenant: Promoting Freedom and Responsibility in the Religious Studies Classroom," CSSR Bulletin 24, no. 2:32-37.

Glennon, Fred. 1999. "Assessment for the Right Reason: The Ethics of Outcomes Assessment." Teaching Theology and Religion 2, no. 1:14-25.

Glennon, Fred. 2004. "Experiential Learning and Social Justice Action: An Experiment in the Scholarship of Teaching and Learning." Teaching Theology and Religion 7, no. $1: 30-37$.
Hiemstra, Roger, and Burton Sisco. 1990. Individualizing Instruction: Making Learning Personal, Empowering, and Successful. San Francisco, Calif.: Jossey-Bass Publishers.

Johnson, David. W., and Roger T. Johnson. 1990. "Cooperative Learning and Achievement." In S. Sharan (Ed.), Cooperative Learning: Theory and Research, 23-38. New York: Greenwood Publishing.

Johnson, David. W., and Roger T. Johnson. 2002. "Social Interdependence Theory and University Instruction: Theory into Practice." Swiss Journal of Psychology 61:119-129.

Johnson, David W., Roger T. Johnson, and Karl Smith. 1991. Active Learning: Cooperation in the College Classroom. Edina, Minn.: Interaction Book Company.

Kegan, Robert. 2000. "What 'Form' Transforms? A Constructive-Developmental Approach to Transformative Learning." In Mezirow \& Associates, Learning as Transformation: Critical Perspectives on a Theory in Progress, 35-69. San Francisco, Calif.: Jossey-Bass Publishers.

Knowles, Malcolm S. 1986. Using Learning Contracts: Practical Approaches to Individualizing and Structuring Learning. San Francisco, Calif.: Jossey-Bass Publishers.

Knowles, Malcolm S., Elwood F. Holton, and Richard A. Swanson. 1998. The Adult Learner. $5^{\text {th }}$ Edition. Woburn, Mass.: Butterworth-Heinemann.

Merriam, Sharan B. 2004. "The Role of Cognitive Development in Mezirow's Transformational Learning Theory." Adult Education Quarterly 55, no. 1:60-68.

Mezirow, Jack. 2000. "Learning to Think Like an Adult: Core Concepts of Transformation Theory." In Mezirow \& Associates, Learning as Transformation: Critical Perspectives on a Theory in Progress, 3-33. San Francisco, Calif.: JosseyBass Publishers.

Palmer, Parker J. 1998. The Courage to Teach. San Francisco, Calif.: Jossey-Bass Publishers.

Schön, Donald A. 1983. The Reflective Practitioner. New York: Basic Books.

Shor, Ira. 1992. Empowering Education: Critical Teaching for Social Change. Chicago, Ill.: University of Chicago Press.

Slavin, Robert E. 1983. Cooperative Learning. New York: Longmans, Inc.

Slavin, Robert E. 1991. "Synthesis of Research on Cooperative Learning.” Educational Leadership 48, no. 2:71-82.

Slavin, Robert E. 1995. "When and Why Does Cooperative Learning Increase Achievement? Theoretical and Empirical Perspectives." In R. Hertz-Lazarowitz and N. Miller (Eds.), Interaction in Cooperative Groups: The Theoretical Anatomy of Group Learning, 145-173. New York: Cambridge University Press.

Summers, Jessica. J., et al. 2005. "Evaluating Collaborative Learning and Community." The Journal of Experimental Education 73, no. 3:165-188.

Zimbardo, Philip. G., et al. 2003. "Cooperative College Examinations: More Gain, Less Pain When Students Share Information and Grades." The Journal of Experimental Education 71, no. 2:101-125.

Zimmerman, Barry J., et al. 1996. Developing Self-Regulated Learners: Beyond Achievement to Self-efficacy. Washington, D.C.: American Psychological Association.

Zimmerman, Barry J. 2002. "Becoming a Self-Regulated Learner: An Overview." Theory into Practice 41, no. 2:6470 . 